Vol. 8, Issue 8, August 2021

DOI: $10.17148 /$ IARJSET.2021.8848

\title{
Political Economy of Social Work Practices
}

\author{
Monika Yadav \\ PhD Research Scholar BMU Rohtak Haryana India
}

\begin{abstract}
The social services are in a precarious position in world. Humans face retrenchment, budgetary constraints that endanger essential services, and unemployment among social sector workers after decades of growth. Traditional political advocates of human services provide only a hesitant and skeptical response to regressive attacks. Political economics is the study of how the dissemination of political and economic power in a society affects the development and policies that affect it. India is a signatory to the "Universal Declaration of Human Rights". It has a "unique mix of justiciable and nonjusticiable rights in its written constitution. The human rights movement in India, as well as its intellectual discourse, has been put to the test owing to the country's unique political complexity, as well as the historical, social, and cultural" differences across its states. Caste, class, and gender discrimination, poverty, a lack of education, and a lack of knowledge are all significant impediments to popularizing and internalizing human rights and turning it into a mass drive. A few people control most of the power in India, where the overwhelming majority of people are impoverished and frequently socially underprivileged, but democratic growth has begun to lessen the grip of elite rule in recent years. It investigates the factors influencing the politics of social practice in India and offers strategies for social workers to develop successful solutions in schooling, rehearsal, philosophy, and investigate.
\end{abstract}

Keywords: Political, Indian Economy, Social Work, Human Rights, Social Group, Economy.

\section{INTRODUCTION}

Social work's position as a self-described "value-based profession" is founded on the scientific methods and standardizing decisions. It integrates data supported study and scrutiny with "principles of human rights and social justice" in its approach to achieving social transformation, empowerment, and human liberation. When social workers have utilized social science to explain the scope and reasons of social issues like poverty, confronted foundations, and a hesitant public to put democratic rhetoric into reality, they have successfully accomplished these objectives. These methods, however small, have had a major effect on all culture during the last century. The profession's ethical obligation to seek social justice and apply this rationale to practise and advocacy reflects distinct political views based on various perspectives and power applications, but this is seldom recognized.

Nevertheless, social workers have lately been more hesitant to face their job's political aspects or oppose those forces whose beliefs and objectives are at odds with their stated purpose. Because "no professional practice can be apolitical," this de-politicization of "social work has significant implications for both service consumers and practitioners in today's radically altered political-economic and ideological environment."

The social services are in a precarious position in world and humans face retrenchment, budgetary constraints that endanger essential services, and unemployment among social sector workers after decades of growth. Traditional political advocates of human services provide only a hesitant and skeptical response to regressive attacks. This dangerous climate is particularly alarming since it comes after a time when the gradual development that started with the progressive movement seemed to explode (Barrera, 2007). Money was plentiful, agencies multiplied, and widespread public 


\section{International Advanced Research Journal in Science, Engineering and Technology}

Vol. 8, Issue 8, August 2021

DOI: $10.17148 / I A R J S E T .2021 .8848$

awareness of the need for an ever-expanding program of services seemed to exist. However, the upbeat atmosphere has already vanished. Workers and customers are frantically trying to rescue certain services from financial ruin. According to the media, there has been a shift in public perception, with a new belief that social services have "failed" and are a waste of public funds (Boram Hwang, 2009).

\section{LITERATURE REVIEW}

From Julia Lathrop's early attempts to create the juvenile court structure to social workers' most current lobbying for widespread health care, the impact of policy practice has been proven all over the history of the social work business (Hornberg, 2002). Throughout history, social workers have impacted the souls of millions of Americans via policy practice. The report looks at the importance of strategy practice in social work and how to employ fundamental social work competencies in policy practice settings to become effective advocates for fair social welfare policies (Hardy, 2014). Policy practice is described as employing social work abilities to recommend and alter policies to accomplish social and economic justice. Policy practice is an essential part of social work in all contexts, including local, state, and national levels of intervention and micro, mezzo, and macro levels of intrusion. Incorporating policy practice into everyday social work practice is a solid and successful way to advance the profession's social and economic justice objectives and purpose (Lai, 2010).

\section{PROBLEM STATEMENT}

Decentralization and federalism are two strategies for making the state more approachable to local demands. Even Though the topmost Indian states are bigger than nearly all nations in the world, the state governments are nevertheless very remote from local people, as shown by the growth of regional parties and the potency of local autonomy activities at the state level. There are two major problems now. One is that, whereas regional governments are fetching more essential in national politics, their fiscal dependency on the central government is rising exponentially: many of them are on the brink of fiscal foreclosure, restricting their economic power and abilities to function numerous effective social service functions (Hornberg, 2002). The other problem is that, as a result of increased regional competition and economic liberalization, the gap between frugally progressive and backward states is widening innovative states progressively resent the redistributive roles of Indian federalism (via the Finance Commission and the Planning Commission), which they perceive as rewarding inefficiency and creating dissent (Osler, 2019).

The human rights effort in India, as well as its scholarly discourse, has been put to the test owing to the country's unique political complexity, and the historical, social, and cultural differences across its states. Caste, socio-economic class, and gender inequality, scarcity, a paucity of schooling, and a lack of understanding are all main impediments to popularising and interiorising human rights and turning it into a people campaign (Lohrenscheit, 2002). With rising social and economical disparities, poverty, spiritual and civil disputes, calamities, and displacements, there is a rising call for social workers to take in the practices which are favorable to human rights. "Human rights practice and security of the rights of the impoverished, marginalized, and most underprivileged people in the nation" need an important foundation in social work practices. (Laskar \& Garg, 2010).

\section{Politics and social work go hand in hand}

Politics has long been an essential part of social work throughout the world, helping to extend civil rights and bring about changes in child wellbeing, healthcare, juvenile justice, and money assistance. What is less well known is that this political engagement developed out of social workers' everyday attempts to improve low-income people and families social and 


\section{International Advanced Research Journal in Science, Engineering and Technology}

Vol. 8, Issue 8, August 2021

DOI: $10.17148 /$ IARJSET.2021.8848

economic circumstances, many of whom were immigrants, in settlement homes, charities, and child welfare organizations (Walkowitz, 1999). After realizing that micro-level actions were insufficient to address daily issues, social workers became involved in politically motivated activities. Before entering the broader political arena, they acknowledged the political character of practice and formed a political awareness about what "Jane Addams" termed "the social question" (Elshtain, 2002). This political awareness impacted their practice's fundamental analytical tenets.

\section{The changing environment in which practice takes place}

Because of substantial modifications in the practice surroundings, the "politics of social work practice" now is considerably distinct from the "politics of social work practice" in the past years. The transformation includes:

- $\quad$ A significant growth in income and asset inequalities.

- An increase in the intensity and chronic nature of poverty.

- An increase in capital's power over labor in the workplace and electoral system.

- Increased job insecurity.

- $\quad$ A decline in the social character of work.

- The destabilization of urban and rural communities.

- A decrease in faith in the system to meet critical issues.

\section{Gist of politics for social work practice}

Politics impact participants' capacity to identify needs, adopt different methods for assisting, and assess their success in social work practice. Among other things, it defines the functions of social workers and clients in the assisting process, as well as the numerous levels of authority that exist within organizations, the degree to which people and groups have influence over strategic goals and program objectives, how information is shared as well as with whom it is shared, and the terminology that is used to describe the service transaction itself. In social work, power, which is at the heart of politics, takes various forms: individual and communal, coercive and cooperative, temporary and perpetual, applied and emblematic, but it often appears in subtle, almost undetectable ways (Schram, 2006).

"Politics also has an impact on the structure of programs at the organizational and community levels, as well as the formal and informal decision-making processes within agencies, the criteria" used by funders to allocate "resources, and the interpersonal dynamics of worker-client and collegial relationships. Politics affects the distribution of those 'goods' over which social service" organizations have authority in each of these cases, including choices regarding worker "time, skills, and resources. However, social workers' ability to exercise these choices is constrained by other people's priorities, particularly individuals and organizations' political and economic interests with different goals, such as politicians, foundations, and individual donors."

\section{Social and Economic Gap}

Human assets (such as education) have a significantly higher level of inequality than physical or financial capital. Corresponding to World Bank estimates, adult education discrimination in India is considerably greater than in not just Sri Lanka, China, Vietnam, or Indonesia, but also in most Latin American nations, such as Brazil and Mexico. The social and economic gap between those who perform physical labour and those who do not in India is mainly mirrored in the chasm between the educated and the illiterate (Anamika Moktan, 2016). The Indian elite may be more divided in conditions of social and economic divides than the elites of most other nations, indicating the fact that India has one of 


\section{International Advanced Research Journal in Science, Engineering and Technology}

Vol. 8, Issue 8, August 2021

DOI: $10.17148 /$ IARJSET.2021.8848

the globe's most diverse populations. This leads to what political scientists refer to as a "collective action" issue, in which the actors struggle to coordinate their actions (Pyles, 2007). It's more complicated for them to settle on an objective, and even if they do, coordinating their activities to accomplish that goal is difficult. When it comes to long-term public infrastructure investment, this becomes a particularly severe political-economic issue (power, roads, transport, telecommunication, ports, irrigation, etc.). Infrastructure is generally considered as a critical barrier for India's economic development, and any improvements in infrastructure would mostly benefit the Indian elite (Das, 2001).

\section{In action conceptualizing policy practice}

Each of the concentric rings of the environment surrounding people and assisting them in fulfilling their fundamental requirements provides opportunities for policy practice. In four distinct contexts within the social environment, social workers try to influence policymaking (Hardy, 2014). The executive department of government (from the Parliament and CMs to state councils and local MPs \& MLAs) can enforce and enact the decisions and measures rolled by the parliament, whether it is Upper or lower house, the state legislature, or the city council, through their corresponding democratic procedures. Social workers may impact policymaking in all three departments of administration (director, legislative, and judicial), but the disputes are distinct in each, prompting various approaches (Sayer, 2017). The judicial arm of the government determines whether or not laws have been broken and whether or not such laws are still valid at the state and federal levels. (Sherman \& Mitchell, 2017).

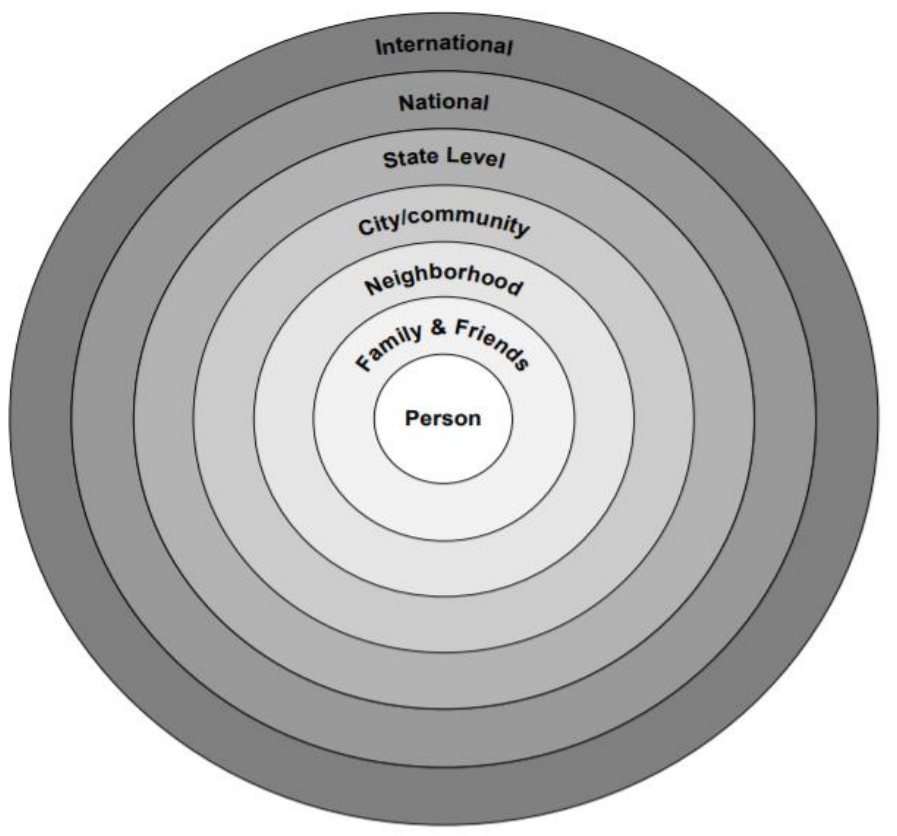

\section{Current position of social and economic interest groups}

When social and economic interest groups are split, pushing in different directions and none of them dominating the entire show, state policies are thrown about, and any enhancements in the direction of economic transformation are likely to be cautious and delayed (Nadkarni \& Sinha, 2016). Fragmentation, on the other hand, might offer the state greater freedom in that it does not have to march to the beat of a single leading interest group, and wise governmental leadership may to some degree push one group off against the other to gain its rent in the shape of unique authority and privileges. In any case, as old debates between Marxist scholars on the "relative autonomy of the state" illustrated, the state management 


\section{International Advanced Research Journal in Science, Engineering and Technology}

Vol. 8, Issue 8, August 2021

DOI: $10.17148 /$ IARJSET.2021.8848

recollects a great deal of efficacy as an administrative actor in cognitive appraisal, programme setting, and policy implementation in most countries, even when acting within the broad constrictions of interest group politics (McMurtry, 2011). Despite economic liberalization, India's state has accumulated a significant degree of power in explicit ownership and regulation of the economy, and it still controls output, properties, and employment in major sections of the controlled non-agricultural zones (Ramamurthy, 2011). Even if the state is the Financing authority for a few of these services, that doesn't imply that the de facto delivery of the services must be bureaucratic. There's a uprising body of populace perception that the state ought to reconfigure its role away from public proprietorship and management of corporate entities and toward more basic social support for the poor (Das, 2001). However, in India, political adoption of this viewpoint has been sluggish. The irony is that despite being influential (and often heavy-handed) in its supervisory and dominant role, India would not be characterized as a 'strong state' in the political economics literature. The latter implies to a state that can plausibly devote to a long-term programme and not stray from it in response to short-term democratic demands (McNutt, 2010).

\section{DISCUSSION}

Social workers must demonstrate their effectiveness in today's political climate even while explaining to whom they owe their primary commitment. (Lorenz, 2006). Anti-discriminatory practice in India and critical social work practice are two examples of responses to this issue. Many of the features of a social movement are shared by social work as a form of collective action. Unlike any other organized occupation, its practitioners believe that people have the power to shape their history. In today's political climate, the profession must reaffirm this principle since it represents a different perspective on individuals, society, and change. It also helps to redefine current discourse, moving away from dealing with the effects of economic globalization, demographic changes, and technological advancements and toward a criticism that emphasizes new kinds of justice and social inclusion. However, criticizing current circumstances without providing new ideas and the tools to put them into action is inadequate. As a result, an alternative language must contextualize current "social work practice without jeopardizing the profession's core principles. This may require rejecting longstanding social role dichotomies inherent in social welfare systems, such as between donors and recipients and between institutional and mutual assistance. It may also mean admitting that the conventional division of practice and education into "silos" isn't working anymore. To enhance their chances of success, social "workers must make their arguments more politically compelling to the broader populace, other practitioners, and the societies in which they work and overcome a long-standing obstacle to the politicization of social work. It is unclear, however, under what institutional cover a repoliticized profession could function."

It stresses the need for cultivating independent political backing, forming and upholding broad-based alliances with new, from time-to-time unexpected associates, and encouraging expressive involvement in the assistance process by all stakeholders.

\section{CONCLUSION}

Theory and practice in social work are more intricately linked with a human rights approach than in any previous social science. Provided that field experiences are the most effective way for social work trainees to learn about human rights, the first step in educating social workers in human rights is to make social work scholastic organizations living models for valuing and fostering human rights (Anamika Moktan, 2016). They must develop into associations where students do not feel powerless. Discriminatory behaviors and biases against students and employees from disadvantaged groups may be eliminated with a written human resource policy. This is particularly relevant in the Indian context, where education has persisted out of touch for the poor, particularly tribals, Muslims, and Dalits (Mukherji, 2009). The fight for social 


\title{
International Advanced Research Journal in Science, Engineering and Technology
}

\author{
Vol. 8, Issue 8, August 2021
}

\section{DOI: 10.17148/IARJSET.2021.8848}

welfare will have to be deliberately political and in ways that have never been seen before (Singh, 2019). Partisans for social welfare must learn to identify adversaries and allies and see political problems as power struggles. Because the corporate elite's traditional backers are unreliable at best, social welfare must rely on a broad base of support from various segments of the population, including the vast majority of Americans whose interests are fundamentally opposed to the elite's (Wincott, 2001). The origins of policy practice may be traced in the profession's early days, particularly in the settlement house movement, which continues to offer a solid basis for policy practice in the twenty-first century (Lai, 2010). Of course, this implies that social welfare must forsake the "expert" above politics position, which is a remnant of the heyday of corporate liberalism. Social welfare's work has always had political ramifications. It was only the monopoly sector corporate elite's near-total control that allowed that stratum's policies to seem like the only feasible results of science and intelligence (Sayer, 2017).

\section{REFERENCES}

1. Anamika Moktan. (2016). Decent Work Deficit in India: A Disaggregated Trend over the Three Post-Reform Decades. World Review of Political Economy, 7(4), 486. https://doi.org/10.13169/worlrevipoliecon.7.4.0486

2. Barrera, A. (2007). Poverty, Work and Freedom: Political Economy and the Moral Order. Review of Social Economy, 65(2), $241-244$. https://doi.org/10.1080/00346760600711909

3. Boram Hwang. (2009). Defining the Substance of the Social Care Policy: the late Modern welfare state and the political economy of the distinction of the public-private. Social Welfare Policy, 36(4), 1-26. https://doi.org/10.15855/swp.2009.36.4.1

4. Das, R. (2001). The Political Economy of India. New Political Economy, 6(1), 103-117. https://doi.org/10.1080/13563460020027786

5. Hardy, M. (2014). Social Injustice: Essays in Political Philosophy. Ethics and Social Welfare, 8(4), 429-431. https://doi.org/10.1080/17496535.2014.956987

6. Hornberg, S. (2002). Human Rights Education as an Integral Part of General Education. International Review of Education / Internationale Zeitschrift Für Erziehungswissenschaft / Revue Internationale de L'Education, 48(3/4), 187-198. http://www.jstor.org/stable/3445360

7. Lai, D. (2010). The political economy of social security development in Macao. China Journal of Social Work, 3(1), 65-81. https://doi.org/10.1080/17525090903560655

8. Laskar, A., \& Garg, S. (2010). Community-based monitoring: Key to success of national health programs. Indian Journal of Community Medicine, 35(2), 214. https://doi.org/10.4103/0970-0218.66857

9. Lohrenscheit, C. (2002). International Approaches in Human Rights Education. International Review of Education / Internationale Zeitschrift Für Erziehungswissenschaft / Revue Internationale de L'Education, 48(3/4), 173-185. http://www.jstor.org/stable/3445359

10. Lorenz, W. (2006) 'The transformation of social work: Professionalism and accountability in the age of neo-liberalism', unpublished paper presented at the 2006 Social Work and Society Conference, Bielefeld, Germany, 12 October.

11. McMurtry, J. (2011). Human Rights versus Corporate Rights: Life Value, the Civil Commons and Social Justice. Studies in Social Justice, 5(1), 11-61. https://doi.org/10.26522/ssj.v5i1.991

12. McNutt, J. (2010). Is Social Work Advocacy Worth the Cost? Issues and Barriers to an Economic Analysis of Social Work Political Practice. Research on Social Work Practice, 21(4), 397-403. https://doi.org/10.1177/1049731510386624

13. Mukherji, R. (2009). The Political Economy of India. https://crawford.anu.edu.au/acde/events/past/tradeandindustry/papers/Paper_9_Mukherji.pdf

14. Nadkarni, V. V., \& Sinha, R. (2016). Transforming Social Work Education in India: Integrating Human Rights. Journal of Human Rights and Social Work, 1(1), 9-18. https://doi.org/10.1007/s41134-016-0002-3

15. Osler, A. (2019). Addressing the "why", "what" and "how" of human rights education. Human Rights Education Review, 2(1), 01-04. https://doi.org/10.7577/hrer.3506

16. Pyles, L. (2007). Measuring the Informal Economy: A Validation Study of the Resource Generating Strategies Scale. Research on Social Work Practice, 17(4), 466-473. https://doi.org/10.1177/1049731506296823

17. R, J., \& Scaria, D. M. (2019). Subaltern Modernity in Context: The Politics of Land in the Life Narrative of Seleena Prakkanam. Journal of Advanced Research in Dynamical and Control Systems, 11(11-SPECIAL ISSUE), 816-819. https://doi.org/10.5373/jardcs/v11sp11/20193101

18. Ramamurthy, S. (2011). Towards a human rights compatible nuclear liability regime: some human rights reflections from India. The International Journal of Human Rights, 15(8), 1234-1248. https://doi.org/10.1080/13642987.2010.511998

19. Sayer, A. (2017). Welfare and Moral Economy. Ethics and Social Welfare, 12(1), 20-33. https://doi.org/10.1080/17496535.2017.1377273

20. Sherman, A., \& Mitchell, T. (2017). Economic Security Programs Help Low-Income Children Succeed Long-Term. Challenge, 60(6), 514542. https://doi.org/10.1080/05775132.2017.1399631

21. Singh, N. (2019, January 26). Understanding political economy for India's future growth. The Financial Express. https://www.financialexpress.com/opinion/understanding-political-economy-for-indias-future-growth/1455343/

22. Specht, H. and Courtenay, M. (1994) Unfaithful Angels: How Social Work Abandoned Its Mission, New York, Free Press.

23. Wincott, D. (2001). Reassessing the Social Foundations of Welfare (State) Regimes. New Political Economy, 6(3), 409-425. https://doi.org/10.1080/13563460120091405

24. Schram, S. F. (2006) Welfare Discipline: Discourse, Governance, and Globalization, Philadelphia, Temple University Press.

25. Weinberg, M. (2010) 'The social construction of social work ethics: Politicizing and broadening the lens', Journal of Progressive Human Services, 21(1), pp. 32-44.

26. Sharath A.M. "The Challenges of Poverty, Types and Its Causes". International Research Journal on Advanced Science Hub, 2, Special Issue ICAMET 10S, 2020, 81-85. doi: 10.47392/irjash.2020.203 